\title{
STRATEGI BISNIS PT. PARIWARA ADVERTISING DI INDUSTRI MEDIA LUAR RUANG
} DKI JAKARTA

\author{
Mila Kumala*)1, Rina Oktaviani**), dan Agus Maulana ${ }^{* * *}$ \\ *) Panin Bank Kantor Cabang Bekasi Square, Kota Bekasi \\ Jl. Ahmad Yani No 57-58,Kios UG 182-183, Bekasi 17148 \\ **) Departemen Ilmu Ekonomi, Fakultas Ekonomi Dan Manajemen, Institut Pertanian Bogor \\ Gedung FEM Lt. 2 Jl. Kamper, Kampus IPB Dramaga Bogor 16680 \\ ${ }^{* * *)}$ Universitas Dr Sutomo \\ Jl. Semmolowaru No. 84, Surabaya, Jawa Timur 6011
}

\begin{abstract}
The objective of the research is to analyze the internal and external condition of PT Pariwara advertising to formulate an appropriate strategy due to the company's declining condition. This condition is caused by the implementation of Pergub No.1 tahun 2015 on the banning of cigarette and tobacco product advertisement in outdoor Medias. The data is analyzed using internal factor evaluation (IFE), External Factor Evaluation (EFE), grand strategy matrix, SWOT and Quantitative Strategic Planning Matrix (QSPM). The result of the research shows that the strategy priority during a stagnant condition is applying the concentric diversification strategy which adding new product that has the similar technology, join facilities, or distribution network with the current product.
\end{abstract}

Keywords: IFE, EFE, SWOT, grand strategy, QSPM

\begin{abstract}
ABSTRAK
Penelitian ini bertujuan menganalisis kondisi internal dan eksternal PT. Pariwara Advertising untuk merumuskan strategi yang tepat ditengah kondisi perusahaan yang sedang menurun dan kondisi industri media luar ruang DKI Jakarta yang melemah karena diterapkannya Pergub No. 1 Tahun 2015 tentang Larangan Penyelenggaraan Reklame Rokok dan Produk Tembakau pada Media Luar Ruang. Teknik analisis data menggunakan analisis internal factor evaluation (IFE), External Factor Evaluation (EFE), matriks strategi besar, matriks SWOT dan Quantitative Strategic Planning Matrix (QSPM). Hasil penelitian ini menunjukan prioritas strategi yang harus dilakukan di tengah kondisi industri yang stagnan adalah dengan strategi diverisifikasi konsentris yaitu strategi penambahan produk baru yang masih ada kaitannya dalam hal kesamaan teknologi, fasilitas bersama, atau jaringan pemasaran yang sama dengan produk yang ada saat ini.
\end{abstract}

Kata kunci: EFI, EFE, SWOT, strategi besar, QSPM

${ }^{1}$ Alamat Korespondensi:

Email: milakumala88@gmail.com 


\section{PENDAHULUAN}

Media luar ruang adalah media iklan yang sering digunakan untuk membangun atau mengenalkan sebuah produk, dengan lebih efektif dalam membangun cakupan pengaruh iklan yang lebih luas dengan frekuensi tayang iklan yang tinggi. Media luar ruang merupakan media iklan paling menarik karena mampu mencapai objek iklan yang lebih banyak bepergian daripada tinggal di rumah (Francese, 2003). Dalam industri media luar ruang DKI Jakarta, terdapat 5 kategori pelaku bisnis yang saling terkait satu sama lain, yaitu pemilik tanah (land owner) yang memiliki atau mengelola lokasi strategis yang cocok untuk iklan media luar ruang seperti billboard, Pemilik/penyewa titik iklan (Media owner) yang membeli atau menyewa lokasi strategis dari land owner untuk kemudian dijual sebagai titik iklan kepada advertisers, specialist outdoor buyers adalah pelaku bisnis yang fokus kepada konten dan kreativitas iklan media luar ruang, Media Agensi adalah pelaku bisnis yang fokus kepada konten dan kreativitas di seluruh jenis iklan bukan hanya iklan media luar ruang, dan yang terakhir adalah pengiklan itu sendiri yang mengiklankan produknya melalui pelaku bisnis media luar ruang DKI Jakarta.

Dalam industri media luar ruang DKI Jakarta, Billboard adalah salah satu media luar ruang yang efektif untuk menjangkau khalayak yang besar. Iklan billboard dirancang untuk menangkap perhatian seseorang dan membuat kesan yang tak terlupakan dengan durasi cepat dan mendorong konsumen untuk memikirkan produk yang diiklankan (Kumar dan Anil, 2012). Namun dibalik kelebihan tersebut, kondisi lingkungan eksternal sangat berpengaruh terhadap kemajuan dari bisnis media luar ruang di DKI Jakarta. Kebijakan Gubernur DKI Jakarta Basuki Tjahaja Purnama (Ahok) melarang iklan luar ruangan atau outdoor produk rokok oleh Pemerintah Provinsi (Pemprov) DKI Jakarta membuat omzet pelaku bisnis media luar ruang menyusut drastis akibat kebijakan tersebut. Sekitar 44\% dari 1700-an titik media iklan outdoor saat ini kosong, sebagian besar karena larangan iklan rokok di tempat umum. Dari jumlah media outdoor yang kosong tersebut, penurunan rokok menjadi penyumbang terbesar yakni $22,51 \%$, diikuti real estate $12,59 \%$, perbankan $5,04 \%$, dan telekomunikasi 3,86\%. Kondisi ini membuat sejumlah pemilik media outdoor merugi cukup besar (Bachdar, 2015).
Kebijakan lain yang akan diberlakukan adalah semua papan billboard akan diganti dengan sistem LED dengan tujuan untuk merapikan dan membentuk estetika kota Jakarta. Gubernur DKI Jakarta, Basuki Tjahaja Purnama tengah menyiapkan peraturan gubernur tentang pelarangan media luar ruang baliho dan billboard. Mulai tahun 2016, media luar ruang di DKI Jakarta hanya akan diijinkan dalam bentuk large electronic display atau LED (Rahadian, 2015).

Hal ini berdampak secara langsung kepada PT. Pariwara Advertising, dimana PT. Pariwara Advertising cukup mengalami hambatan dalam menghadapi perubahan ligkungan eksternal yang dinamis. Pada Gambar 1 terlihat bahwa terjadi penurunan penjualan yang cukup signifikan terjadi pada PT. Pariwara Advertising selama kurun waktu 2012-2015. Tercatat pada tahun 2012 nilai penjualan mencapai Rp31,3 Milyar, Namun pada tahun 2013 terjadi penurunan penjualan dengan selisih sebesar 11 Milyar rupiah, menjadi Rp20,1 M kemudian drastis turun kembali menjadi Rp15,7 M pada tahun 2014. Sampai dengan tahun 2015, tercatat penjualan yang diperoleh PT. Pariwara Advertising hanya sebesar Rp5 Milyar. Kondisi penjualan yang terus menurun ini memberikan dampak yang cukup signifikan terhadap lingkungan internal bisnis PT. Pariwara Advertising salah satunya dengan kebijakan pengurangan karyawan untuk menjaga efektifitas kinerja perusahaan disamping beban kerugian yang semakin tinggi.

Namun, penurunan penjualan tidak hanya terjadi pada Pariwara saja, di industri media luar ruang DKI Jakarta hampir seluruh perusahaan media luar ruang mengalami kondisi yang sama dikarenakan lingkungan eksternal perusahaan yang sangat memengaruhi kinerja perusahaan. Terlihat pada Gambar 1, PT. Cipta Lestari Mandiri mengalami penurunan penjualan yang sama sampai kurun waktu tahun 2015.

Penelitian yang sesuai dan mendukung penelitian ini adalah Thamrin (2012), menjelaskan bahwa seiring dengan perkembangan bisnis yang semakin meningkat, reklame menjadi salah satu media promosi yang menunjang kemajuan bisnis suatu perusahaan. Adapun jenis-jenis reklame antara lain reklame spanduk, papan billboard, reklame bersinar, reklame kain, reklame stiker dan reklame papan merek. Wicaksono et al. (2008) menyimpulkan bahwa selama ini penempatan media luar ruang masih dengan pendekatan ekonomi sehingga kepentingan publik banyak yang dikorbankan. 
Hal ini selaras dengan respon masyarakat terhadap iklan luar ruang yang terganggu dengan iklan luar ruang yang memiliki intensitas tinggi sehingga menyebabkan tumpang tindih titik iklan. Mendukung penelitian tersebut, menurut Juniarko (2013), dalam menjalankan strategi bisnis outdoor advertising, pendekatan yang dilakukan untuk menempatkan media outdoor advertisingselamainilebihkepadapendekatan ekonomi. Kondisi eksisting pemasangan setiap iklan menunjukan bahwa tidak adanya kesesuaian antara elemen penataan dengan koridor jalan. Bahwa media ruang luar/reklame memang memengaruhi kualitas wajah kota, karena itu harus dilakukan perencanaan penataan media ruang luar/reklame yang baik dengan menimbang banyak hal seperti kepentingan masyarakat, pemilik media, lingkungan, peraturan perundang-undangan, serta visi dan misi daerah (Harysakti, 2013).

Menurut penelitian Taylor et al. (2006), faktanya untuk menjadikan iklan dapat diingat oleh masyarakat sangat sulit sekali. Dibutuhkah konten yang menarik dan lokasi yang strategis jika menggunakan outdoor advertising. Bagaimanapun juga, industri periklanan tidak bisa berdiri sendiri, keterkaitan antar stakeholder menjadikan pamor outdoor advertising semakin tinggi.

Menurut Ekomadyo (2008), keberadaan media luar ruang secara substansial memberikan nilai positif untuk meningkatkan estetika kita. Faktor kunci untuk menjadikan media luar ruang bersinergi dengan kota dibutuhkan upaya konkrit dari pemerintah dengan mengakomodasi politik dan hukum untuk mengatur industri media luar ruang. Kepentingan iklan luar ruang yang tertata dan terencana menjadi sesuatu yang harus dipertimbangkan dan diteliti lebih lanjut terutama dalam hal membentuk identitas kota (Defriza, 2006).

Sedangkan penelitian yang sesuai dengan metodologi penelitian ini adalah Isnandar (2016), The Quantitative Strategy Planning Matrix (QSPM) bertujuan menentukan pemilihan strategi yang tepat atau yang terbaik dalam hal memutuskan strategi apa yang akan dijalankan oleh perusahaan pada jangka pendek maupun jangka panjang. Selanjutnya, menurut sholehana (2012), Evaluasi faktor internal dan eksternal dilakukan untuk mengetahui kekuatan dan kelemahan utama yang dimiliki oleh perusahaan, serta peluang dan ancaman utama yang akan dihadapi oleh perusahaan. Kekuatan dan kelemahan utama dilihat dari nilai tertimbang terbesar, dan begitu juga dengan peluang dan ancaman utama. Sedangkan untuk memudahkan dalam implementasi analisis SWOT diperlukan konstruksi matriks SWOT, dengan mengkombinasikan faktor kekuatan, kelemahan, peluang, dan ancaman (Rahmana et al. 2013). Setelah dilakukan SWOT maka untuk mengetahui alternatif strategi yang cocok dengan posisi kompetitif perusahaan digunakanlah matriks strategi besar agar strategi yang dipilih dapat menjawab permasalahan perusahaan (Lukito et al. 2013).

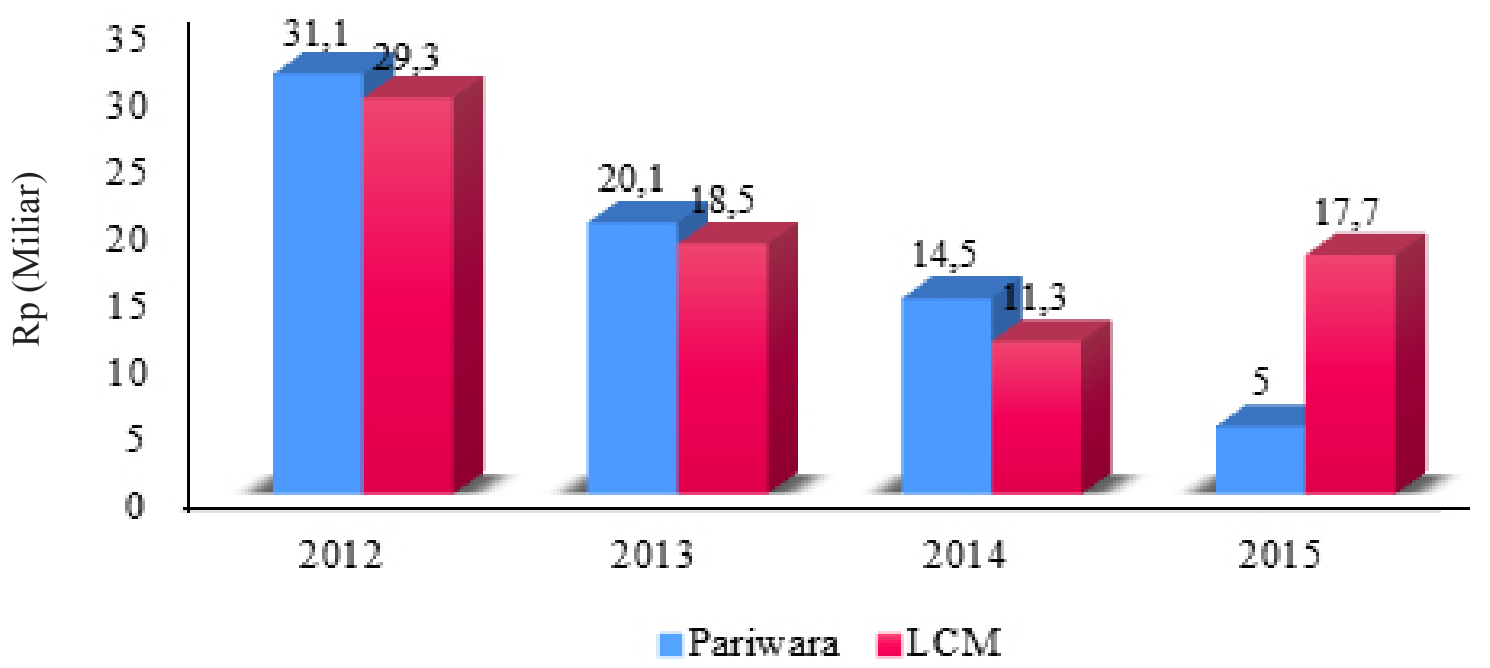

Gambar 1. Perbandingan jumlah penjualan PT. Pariwara Advertising (Pariwara) dan PT. Lestari Cipta Mandiri $(\mathrm{LCM})$ 
Di lingkungan yang dinamis dan tidak menentu, sebuah perusahaan memerlukan perencanaan yang mampu memberikan sarana sistematis untuk menganalisis lingkungan, menilai kekuatan organisasi, dan mengidentifikasi peluang untuk mengembangkan dan memanfaatkan keunggulan bersaing (Ginting, 2006). Tujuan penelitian ini adalah menganalisis kondisi internal dan eksternal PT. Pariwara Advertising guna menemukan strategi yang tepat agar perusahaan tetap eksis di industri media luar ruang DKI Jakarta. Adapun ruang lingkup penelitian ini adalah formulasi strategi untuk meningkatkan penjualan PT. Pariwara Advertising.

\section{METODE PENELITIAN}

Pada kajian ini pengambilan data primer dilakukan dengan in-depth interview secara terstuktur dan Kuesioner dengan pakar dan stakeholder di industri outdoor advertising di Indonesia, sedangkan data sekunder diperoleh dari studi pustaka yang tersedia dan data-data yang tersedia di berbagai instansi. Wawancara digunakan untuk memperluas cakrawala peneliti tentang data lain yang tidak terformulasi dalam kuesioner, namun akan memiliki implikasi strategis bagi perusahaan sehingga layak untuk dilakukan penelitian lebih lanjut. selain itu wawancara juga digunakan untuk melengkapi data terkumpul melalui kuesioner (Soesatyo dan Rumambi, 2013).

Pengambilan data berupa pendapat para ahli dilakukan melalui wawancara mendalam (depth interview) dan Kuesioner terstruktur. Responden dipilih melalui pendekatan expertise judgemental, dengan cara menentukan terlebih dahulu responden ahli yang akan diwawancara, agar diperoleh gambaran menyeluruh tentang kinerja dan permasalahan yang dihadapi industri dalam kaitannya dengan strategi pengembangan bisnis industri outdoor advertising di Indonesia. Kriteria responden adalah pihak-pihak yang berhubungan langsung dalam perkembangan industri outdoor advertising di Indonesia.

Data primer yang dibutuhkan dalam penelitian ini akan diperoleh dengan secara langsung mewawancarai direktur, manajer marketing, manajer operasional, dan staf legal PT. Pariwara Advertising yang memiliki kapasitas dalammenjawab setiap pertanyaan wawancara guna memahami alur bisnis dari Pariwara. Kemudian untuk menguatkan hasil wawancara, perolehan data juga dilakukan melalui kuesioner, yaitu dengan cara memberikan serangkaian pertanyaan tertulis dan daftar isian untuk mendapatkan data dan informasi dari responden yang dipilih. Pemilihan responden pada penelitian dilakukan dengan mempertimbangkan pemahaman responden terhadap kondisi industri media luar ruang di DKI Jakarta. Pada Tabel 1 memaparkan bahwa jumlah responden dalam penelitian ini terdiri dari 12 orang pakar dengan memiliki pemahaman mendalam dan berkecimpung langsung dalam industri media luar ruang DKI Jakarta. Suyitman et al. (2009) mengemukakan bahwa persyaratan responden pakar antara lain memiliki pengalaman yang kompeten sesuai bidang yang dikaji, memiliki reputasi, kedudukan atau jabatan dalam kompetensinya dengan bidang yang dikaji, memiliki komitmen terhadap permasalahan yang dikaji, bersifat netral dan bersedia menerima pendapat responden lain dan memiliki kredibilitas tinggi dan bersedia dimintai pendapat. Responden selengkapnya pada Tabel 1 .

Tabel 1. Daftar nama pakar

\begin{tabular}{lll}
\hline \multicolumn{1}{c}{ Nama } & \multicolumn{1}{c}{ Jabatan } & \multicolumn{1}{c}{ Perusahaan } \\
\hline Hana & Staf Dinas Tata & PEMDA DKI \\
& Kota & Jakarta \\
Didi Oerip & Ketua & Serikat Pekerja \\
Affandi & & $\begin{array}{l}\text { Reklame Jakarta } \\
\text { (SPRJ) }\end{array}$ \\
Immanuel & Direktur & Cepek \\
Juniawan & & Advertising \\
Gunadi & Anggota & Asosiasi Media \\
& & Luar Indonesia \\
& & (AMLI) \\
Agus Priambodo & Manajemen & Posterscop \\
Dewi Anggraeni & Manajemen & PT. Lestari Cipta \\
& & Mandiri \\
Andi Mulia & Manajemen & Maxxima \\
& & Advertising \\
Putra Fajar & CEO & PT. Pariwara \\
& & Advertising \\
Tommy & Manajer & PT. Pariwara \\
Nurvrihadhi & Operasional & Advertising \\
Dedi Afrianto & Manajer Finance & PT. Pariwara \\
& dan SDM & Advertising \\
Cuntari & Staf Legal & PT. Pariwara \\
& & Advertising \\
Chaerul & Staf Marketing & PT. Lestari Cipta \\
& & Mandiri \\
\hline
\end{tabular}

Desain penelitian menggunakan studi kasus (case study) yang dirancang khusus untuk mempelajari secara mendalam sebuah permasalahan yang terjadi di industri media luar ruang DKI Jakarta khususnya di 
PT. Pariwara Advertising. Dengan metode deskriptif, peneliti akan menganalisis dan mengumpulkan berbagai data untuk menjawab permasalahan yang ada dan bagaimana model bisnis yang akan dibangun oleh perusahaan. Penelitian ini juga mencakup analisis kondisi lingkungan internal maupun eksternal perusahaan untuk dapat menggambarkan kondisi sebenarnya dari PT. Pariwara Advertising dalam industri media luar ruang di Indonesia. Analisis kualitatif dilakukan dengan menggunakan Kuesioner yang ditujukan untuk mengeksplorasi faktor-faktor strategis internal dan eksternal lalu diolah SWOT, grand strategi dan QSPM.

Menurut Sholihin (2014), Matriks Evaluasi Faktor Internal adalah metode analisis sistematis menentukan faktor-faktor keunggulan strategi yang dimiliki oleh perusahaan. Dalam membuat Matriks EFI, langkah pertama adalah membuat daftar faktor-faktor internal utama. Kemudia diberi bobot pada setiap faktor tersebut, Jumlah total seluruh bobot harus sama dengan 1,0. Setelah itu berilah peringkat antara 1 sampai 4 pada setiap faktor eksternal utama untuk menunjukan seberapa efektif strategi perusahaan saat ini dalam merespon faktor tersebut. Kalikan bobot setiap faktor dengan peringkatnya untuk menentukan skor bobot bagi masing-masing variabel. Jumlahkan skor bobot masing-masing variabel untuk memperoleh skor bobot total organisasi.

Menurut David (2006) tahapan-tahapan dalam membuat matriks EFE adalah membuat daftar faktorfaktor eksternal utama. Lalu diberi bobot pada setiap faktor tersebut.Kemudian berilah peringkat antara 1 sampai 4 pada setiap faktor eksternal utama untuk menunjukan seberapa efektif strategi perusahaan saat ini dalam merespon faktor tersebut. Kalikan bobot setiap faktor dengan peringkatnya untuk menentukan skor bobot. Lalu Jumlahkan skor rata-rata untuk setiap variabel guna menentukan skor bobot total untuk organisasi. EFE digunakan untuk mengevaluasi faktorfaktor eksternal perusahaan. Data ekstemal dikumpulkan untuk menganalisis hal-hal yang menyangkut persoalan ekonomi, sosial, budaya, demografi, lingkungan, politik, pemerintah, hukum, teknologi, persaingan dalam pasar industri, serta data eksternal relevan lainnya (Setiawan et al. 2015).

Analisis SWOT adalah sebuah metode perencanaan strategis yang digunakan untuk mengevaluasi Strengths, Weakness, Opportunities, dan Threats terlibat dalam suatu proyek atau dalam bisnis usaha. Hal ini melibatkan penentuan tujuan usaha bisnis atau proyek dan mengidentifikasi faktor-faktor internal dan eksternal yang baik dan menguntungkan untuk mencapai tujuan bisnis (Anwar dan Utami, 2012). Jannah et al. (2013) mengemukakan bahwa, alat yang dipakai untuk menyusun faktor-faktor strategis perusahaan adalah matriks SWOT yang dapat menggambarkan secara jelas bagaimana peluang dan ancaman eksternal yang dihadapi perusahaan dapat diselesaikan dengan kekuatan dan kelemahan yang dimilikinya. Analisis situasi SWOT merupakan awal proses perumusan strategi untuk menemukan kesesuaian strategis antara peluang eksternal dan kekuatan internal, di samping memperhatikan ancaman eksternal dan kelemahan internal (Retnowati, 2011).

Strategi yang sesuai untuk sebuah organisasi dituangkan dalam urutan daya tarik di masing-masing kuadran matriks (Rangkuti, 2004). Dalam kuadran 1, posisi strategik yang bagus, konsentrasi pada pasar atau industri saat ini, ambil risiko secara agresif jika perlu, strategi: intensif, integrasi, diversifikasi konsentris. Dalam kuadran 2, evaluasi kondisi saat ini, perbaiki daya saing, strategi: intensif, integrasi horizontal, divestasi, likuidasi. Kuadran 3, yaitu bersaing pada industri yang pertumbuhan lemah, posisi kompetitif lemah, perlu perubahan drastis secara cepat, pengurangan cost dan asset, strategi: defensive, diversifikasi. Lalu di kuadran 4: posisi kompetitif kuat, pertumbuhan industri lambat, cash flow kuat, strategi: diversifikasi, joint venture. Menurut Guyana dan Mustamu (2013), dalam menentukan strategi alternatif, perusahaan memiliki posisi kompetisi disertai dengan tingkat pertumbuhan pasar yang dinamis. Oleh karena itu dibutuhkan matriks strategi besar untuk mengetahui posisi perusahaan dalam industrinya. QSPM adalah alat untuk mengevaluasi strategi yang akan diterapkan sehingga dapat mengoptimalkan hasil yang diperoleh (Zulkarnaen dan Sutopo, 2013).

Untuk mengetahui kondisi sebenarnya PT. Pariwara Advertising diperlukan analisis lingkungan internal dan eksternal perusahaan. Kondisi internal yang dianalisis berupa kekuatan dan kelemahan yang ada di kebijakan manajemen, sumber daya manusia dan produk media luar ruang. Selanjutnya dilakukan analisis kondisi eksternal berupa ancaman dan peluang yang harus diwaspadai oleh perusahaan. 
Pada Gambar 2 menunjukan bahwa analisis grand strategi diharapkan dapat menentukan kondisi kompetitif PT. Pariwara Advertising yang dapat menjadi peluang di masa depan. Pada tahap penentuan strategi prioritas, digunakanlah QSPM sehingga didapatkanlah strategi utama yang menjadi langkah awal dalam meningkatkan kinerja perusahaan. Selanjutnya, disusunlah perencanaan strategis untuk menjalankan strategi tersebut.

\section{HASIL}

\section{Analisis Lingkungan Internal}

Analisis lingkungan internal bertujuan untuk mengidentifikasi dan menganalisis faktor strategis internal yang Memengaruhi keberlangsungan bisnis PT. Pariwara Advertising. Faktor strategis internal terdiri dari kekuatan dan kelemahan. Kekuatan merupakan faktor strategis internal yang dapat dioptimalkan untuk meningkatkan daya saing PT. Pariwara Advertising sedangkan kelemahan merupakan faktor strategis internal yang harus diperbaiki oleh perusahaan dalam merumuskan faktor penentu kesuksesn PT. Pariwara Advertising. Hasil wawancara kepada repsonden internal didapatlah 5 kekuatan dan 5 kelemahan.

\section{Kekuatan (Strength)}

Kekuatan perusahaan merupakan faktor internal yang harus dikembangkan untuk mendukung strategi perusahaan. Kekuatan perusahaan terbentuk diantaranya dari pengalaman puluhan tahun dan jaringan bisnis yang luas sehingga PT. Pariwara Advertising terus eksis hingga saat ini. Faktor strategis internal yang digolongkan sebagai kekuatan PT. Pariwara Advertising adalah 1) berpengalaman 38 Tahun di industri media luar ruang Jakarta. PT. Pariwara Advertising mulai menjalankan bisnisnya pada tahun 1978. Pengalaman selama puluhan tahun menjadikan PT. Pariwara Advertising lebih unggul dalam jaringan bisnis di industri media luar ruang DKI Jakarta. 2) Harga produk bersaing. Untuk menentukan standar harga produk pada media luar ruang, PT. Pariwara Advertising akan dibandingkan dengan PT. Lestari Cipta Mandiri yaitu perusahaan media luar ruang yang juga telah berdiri selama 20 tahun. Dapat dilihat pada Tabel 2, bahwa Pariwara memiliki harga jual produk yang lebih rendah dibandingkan perusahaan pembanding yaitu PT. Lestari Cipta Mandiri. 3) Kepercayaan klien besar. Pariwara memiliki beberapa klien yang sama dari tahun 2012 sampai dengan 2015. Diantaranya adalah Bank CIMB dan Bank BNI. Dari hasil wawancara dengan klien tersebut, diperoleh kesimpulan bahwa alasan untuk terus menggunakan jasa Pariwara adalah karena Pariwara sangat menjaga kualitas produknya. 4) Budaya perusahaan kuat. Budaya belajar di PT. Pariwara Advertising menjadikan loyalitas terhadap perusahaan tertanam kuat. Selain itu, nilai-nilai integritas dijunjung tinggi dan menjadi ukuran dalam menilai kemauan setiap karyawan Pariwara. 5) Memiliki titik iklan strategis di DKI Jakarta. Berbeda dengan beberapa perusahaan media luar ruang lainnya, Pariwara memiliki 44 titik iklan yang disewa atau dibeli oleh Pariwara. Berbeda dengan PT. Lestari Cipta Mandiri yang hanya memiliki lima titik iklan sehingga ketika menjual titik iklan, harga yang ditawarkan lebih tinggi dibandingkan pariwara karena titik tersebut dimiliki oleh pihak lain, dan LCM hanya sebagai perantara.

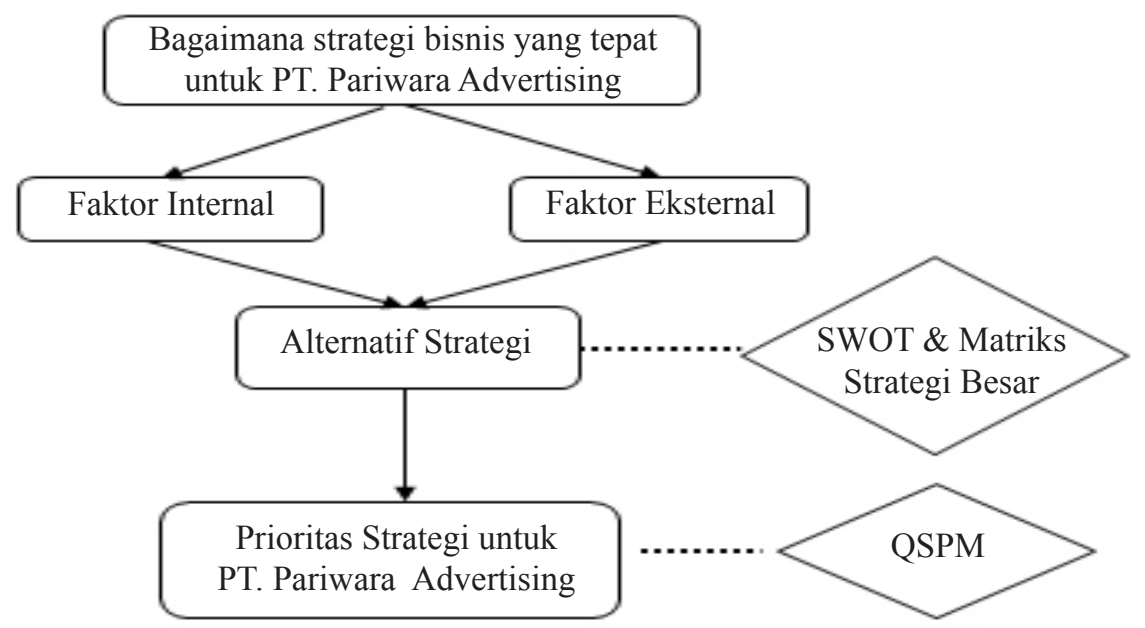

Gambar 2. Kerangka pemikiran penelitian 
Tabel. 2 Perbandingan harga produk

\begin{tabular}{lcr}
\hline \multicolumn{1}{c}{ Produk } & \multicolumn{1}{c}{ Pariwara } & \multicolumn{1}{c}{ LCM } \\
\hline Billboard (Rp) & 799.000 .000 & 813.000000 \\
LED (Rp) & 1.521 .000 .000 & 1.613 .466 .667 \\
\hline
\end{tabular}

\section{Kelemahan (Weakness)}

Setiap perusahaan tumbuh tidak hanya membawa kesuksesan yang dapat diukur melalui jumlah profit yang dihasilkan. Pertumbuhan tersebut, lahir dari tantangan bisnis yang mampu dihadapi oleh perusahaan dan salah satu dari tantangan bisnis itu adalah kelemahan yang masih dimiliki perusahaan sehingga berdampak kepada kemajuan perusahaan. Faktor strategis internal yang digolongkan sebagai kelemahan PT. Pariwara Advertising adalah 1) produk didonimasi oleh billboard. Sebanyak $80 \%$ produk PT. Pariwara Advertising didominasi oleh Billboard. Tidak dengan LCM, yang memiliki produk iklan televisi di TVRI sehingga memiliki sumber pemasukan lain selain Billboard. 2) Tingginya turn over karyawan. Pada Tabel 3 terlihat bahwa selama kurun waktu 2014-2015, PT. Pariwara Advertising mengalami pergantian staf dengan jumlah cukup signifikan yaitu sebesar sembilan orang. Penurunan jumlah SDM ini disebabkan kondisi perusahaan. 3) Belum adanya edukasi terhadap klien. Saat ini belum ada tolak ukur yang jelas dalam media luar ruang apakah iklan tersebut tepat sasaran dan berdampak bagi produk karena dengan posisi media luar ruang di ruang publik seperti jalan, kita tidak bisa menganalisis siapa saja yang tertarik atau bahkan sama sekali tidak melihat iklan di billboard tersebut. 4) Menurunnya penjualan. Penjualan PT. Pariwara Advertising yang terus menurun sampai dengan Rp5 Milyar pada tahun 2015, menyebabkan kondisi operasional perusahaan terganggu. Penurunan penjualan juga dialami oleh PT. Lestari Cipta Mandiri, ketika tahun 2012 memiliki jumlah penjualan sebesar Rp29 Milyar, turun pada tahun 2013 menjadi Rp18 Milyar dan turun menjadi 11 Milyar pada tahun 2014. Namun, berbeda dengan Pariwara, LCM melakukan perluasan produk dengan menjangkau produk iklan TV sehingga penjualan pada tahun 2015 dapat kembali naik menjadi Rp17 Milyar. 5) Belum ada divisi riset yang mengukur keandalan produk. Dalam industri media luar ruang dimana produk yang diunggulkan adalah billboard, membuat para pelaku bisnis sulit untuk mengembangkan pangsa pasar karena kompetisi yang sengit.
Tabel 3. Jumlah karyawan PT. Pariwara 2014-2015

\begin{tabular}{lcc}
\hline Divisi pekerjaan & Tahun 2014 & Tahun 2015 \\
\hline $\begin{array}{l}\text { Akunting, } \\
\text { General Affair, }\end{array}$ & 11 orang & 5 orang \\
$\begin{array}{l}\text { Administrasi } \\
\text { Operation (Legal, } \\
\text { officer) }\end{array}$ & 6 orang & 5 orang \\
$\begin{array}{l}\text { Marketing, desain } \\
\text { grafis }\end{array}$ & 6 orang & 4 orang \\
$\begin{array}{l}\text { Sales } \\
\text { Total SDM }\end{array}$ & 5 orang & 5 orang \\
\hline
\end{tabular}

\section{Analisis Faktor Strategis Eksternal}

Analisis lingkungan eksternal bertujuan untuk mengidentifikasi dan menganalisis faktor strategis eksternal yang memengaruhi keberlangsungan PT. Pariwara Advertising di industri media luar ruang di Indonesia. Hasil penelitian menunjukan bahwa terdapat delapan faktor strategis eksternal yang terdiri dari empat peluang dan empat ancaman.

\section{Peluang (Opportunity)}

Peluang adalah situasi penting yang mengguntungkan dalam lingkungan perusahaan. Contohnya adalah perubahan teknologi dan meningkatnya hubungan antara perusahaan dengan pembeli atau pemasok merupakan gambaran peluang bagi perusahaan.Faktor strategis eksternal yang digolongkan sebagai peluang yang dapat dimanfaatkan dalam keberlangsungan bisnis PT. Pariwara Advertising yaitu 1) Potensi produk baru (LED, TV dan media sosial). Pertumbuhan belanja iklan lainnya di tahun 2015, lebih didorong oleh pergerakan yang positif di TV yaitu secara total meningkat sebesar $12 \%$. Tahun 2016, pertumbuhan iklan mobile digital meningkat tiga kali lipat, atau sekitar $15,5 \%$ dari total belanja iklan digital di Indonesia. Meskipun meningkat, jumlah itu hanya $1,1 \%$ dari total belanja iklan media saat ini. Artinya, belanja iklan media digital masih amat minim. Pada akhir tahun 2019, mayoritas belanja iklan digital akan dialokasikan ke arah mobile. Hal inilah yang belum dipersiapkan oleh Pariwara. 2) Mobilitas masyarakat semakin tinggi. Menurut penelitian yang dilakukan oleh Smarter (2015) dengan total 310 responden. Hampir seluruh responden melakukan perjalanan ke tengah kota Jakarta, Separuh responden melakukan perjalanan menuju selatan Jakarta, dengan jalan yang paling banyak dilalui adalah TB Simatupang, Pasar Minggu, dan daerah Kuningan. 3) Pertumbuhan belanja iklan. Menurut laporan Nielsen Advertising Information Services, pertumbuhan belanja iklan 
DKI Jakarta di akhir tahun 2015 bergerak positif. Jika dilihat dari jenis medianya, pertumbuhan belanja iklan di tahun 2015, lebih didorong oleh pergerakan yang positif di TV yaitu secara total meningkat sebesar 12\%. Pertumbuhan belanja iklan koran di kuartal empat tahun 2015 menunjukkan pergerakan yang positif, yaitu tumbuh sebesar $1 \%$. Walaupun angka pertumbuhan tahunan masih menurun sebesar $-4 \%$, tercatat kecenderungannya sudah membaik dibandingkan kuartal-kuartal sebelumnya. Total belanja iklan koran di akhir tahun 2015 mencapai Rp30,8 triliun (www.nielsen.com). 4) Perkembangan Teknologi Informasi. Media luar ruang sangat berpotensi untuk semakin menjual jika bisa terkoneksi dengan aktivitas masyarakat DKI Jakarta di dunia digital. Bila dilihat dari wilayah domisilinya, $78,5 \%$ dari total $\mathrm{Rp} 88,1$ juta pengguna internet di Indonesia tinggal di wilayah Indonesia bagian barat. Ibukota DKI Jakarta menjadi wilayah dengan penetrasi paling tinggi dengan $65 \%$ pengguna internet.

\section{Ancaman (Threats)}

Ancaman adalah situasi penting yang tidak menguntungan dalam lingkungan perusahaan. Ancaman merupakan pengganggu utama bagi posisi sekarang atau yang diinginkan perusahaan. Salah satu ancaman yang sedang dihadapi oleh PT. Pariwara Advertising adalah adanya peraturan-peraturan pemerintah yang tidal bersinergi dengan bisnis media luar ruang di DKI Jakarta. Faktor strategis eksternal yang digolongkan sebagai ancaman yang dapat dimanfaatkan dalam keberlangsungan bisnis PT. Pariwara Advertising, yaitu 1) Regulasi Pemerintah Daerah. Dalam industri media luar ruang, sangat erat dengan regulasi yang ada di pemerintah daerah. setiap Perda atau Pergub yang terbit akan berdampak signifikan terhadap internal perusahaan. Sebagai contoh, pada awal tahun 2015, terbit Pergub terbaru No. 1 Tahun 2015, tentang "Larangan Penyelenggaran Reklame Rokok dan Produk Tembakau Pada Media Luar Ruang”, yang melarang reklame rokok dan produk tembakau pada media luar ruang di seluruh wilayah Provinsi Daerah Khusus Ibukota Jakarta. 2) Estetika Kota, Menurut Gubernur DKI Jakarta, Basuki Tjahaja Purnama (Ahok), keberadaan reklame di Jakarta begitu banyak dan tak terkendali. Ironisnya, selain menutupi estetika gedung dan membahayakan ketika musim hujan, tidak sedikit pemilik reklame yang tidak membayar pajak. Oleh karena itu, setelah proyek Mass Rapid Transit (MRT) rampung pada 2018, seluruh reklame di Jakarta harus berbentuk dengan LED. Peraturan ini dibuat agar estetika kota terjaga dan media luar ruang dapat menyatu dengan kota. 3) Industri Media lain (TV), Nielsen Advertising Information Services mencatat, dari total belanja iklan pada semester I/2015, jatah iklan paling banyak didapat oleh media televisi sekitar Rp41,03 triliun atau 71,7\%. Pertumbuhan ini meningkat $9 \%$ dibandingkan dengan tahun 2014. Hal ini mengindikan bahwa, persaingan media luar ruang bukan hanya terjadi di sesama pelaku media luar ruang. banyaknya ragam media iklan, membuat media luar ruang mulai kehilangan pamornya. Jika di TV, informasi dan kreativitas lebih menarik untuk di nikmati maka media luar ruang harus memberikan nilai baru untuk pengguna iklan agar bisa bersaing dengan media iklan TV. 4) Daya Beli Klien. Iklan rokok menjadi nomer satu penyumbang terbesar kosongnya sejumlah media iklan luar ruangan seperti billboard dan baliho di beberapa sudut Jakarta. Sekitar 30\% dari 1700-an titik media iklan outdoor saat ini kosong, sebagian besar karena larangan iklan rokok di tempat umum. Dari jumlah media outdoor yang kosong tersebut, penurunan rokok menjadi penyumbang terbesar yakni $14,4 \%$, diikuti real estate $12,59 \%$, perbankan $5,04 \%$, dan telekomunikasi $3,86 \%$. Kondisi ini membuat sejumlah pemilik media outdoor merugi cukup besar (http:finance.detik.com).

\section{Matriks Evaluasi Faktor Eksternal}

Hasil dari matriks Evaluasi Faktor Eksternal (EFE) terdapat pada Tabel 4, yaitu skor matriks EFE adalah 2,304. Hal ini menunjukan bahwa respon PT. Pariwara Advertising terhadap peluang dan ancaman yang ada di bawah rata-rata sehingga kondisi eksternal sangat Memengaruhi bisnis PT. Pariwara Advertising.

\section{Matriks Evaluasi Faktor Internal}

Setelah diperoleh faktor strategis internal berupa kekuatan dan kelemahan yang ada dalam PT. Pariwara Advertising, kemudian dilakukan pembobotan dan pemberian peringkat oleh responden internal. Pada Tabel 5 dipaparkan bahwa total skor matriks IFE adalah 2,505 sehingga dapat disimpulkan bahwa respon manajemen terhadap kondisi internal perusahaan cukup baik. 
Tabel 4 . Matriks EFE

\begin{tabular}{|c|c|c|c|}
\hline Peluang & Bobot & Peringkat & Skor \\
\hline Potensi produk baru (LED, media sosial, TV) & 0,100 & 3 & 0,301 \\
\hline Perkembangan teknologi informasi & 0,087 & 2 & 0,174 \\
\hline Mobilitas penduduk tinggi & 0,090 & 2 & 0,179 \\
\hline \multirow[t]{2}{*}{ Pertumbuhan belanja iklan } & 0,088 & 2 & 0,176 \\
\hline & & & 0,831 \\
\hline \multicolumn{4}{|l|}{ Ancaman } \\
\hline Regulasi Pemerintah Daerah DKI Jakarta & 0,151 & 4 & 0,602 \\
\hline Menurunnya daya beli klien billboard & 0,119 & 2 & 0,239 \\
\hline Estetika Kota & 0,102 & 2 & 0,204 \\
\hline \multirow[t]{2}{*}{ Persaingan di Industri iklan lain nya (TV, Media Sosial) } & 0,142 & 3 & 0,427 \\
\hline & & & 1,472 \\
\hline Total & 1 & & 2,304 \\
\hline
\end{tabular}

Tabel 5. Matriks EFI

\begin{tabular}{|c|c|c|c|}
\hline Kekuatan & Bobot & Peringkat & Skor \\
\hline Manajemen puncak berpengalaman & 0,093 & 3 & 0,279 \\
\hline Harga produk bersaing & 0,114 & 4 & 0,457 \\
\hline Tingginya kepercayaan klien & 0,102 & 3 & 0,305 \\
\hline Budaya Pariwara & 0,104 & 4 & 0,414 \\
\hline \multirow[t]{2}{*}{ Lokasi Iklan strategis } & 0,082 & 3 & 0,246 \\
\hline & & & 1,702 \\
\hline \multicolumn{4}{|l|}{ Kelemahan } \\
\hline Produk didominasi oleh billboard & 0,073 & 2 & 0,186 \\
\hline Tingginya turn over karyawan & 0,105 & 2 & 0,229 \\
\hline Belum mengedukasi klien & 0,093 & 2 & 0,204 \\
\hline Menurunnya finansial perusahaan & 0,118 & 1 & 0,104 \\
\hline \multirow[t]{2}{*}{ Belum ada divisi riset yang mengukur keandalan produk } & 0,116 & 1 & 0,082 \\
\hline & & & 0,804 \\
\hline Total & 1 & & 2,505 \\
\hline
\end{tabular}

\section{Matriks SWOT}

Untuk menghasilkan alternatif strategi yang tepat dibutuhkan analisis mendalam terhadap kekuatan, kelemahan, peluang dan ancaman yang dimiliki oleh PT. Pariwara Advertising. Pada gambar 3 di bawah ini dapat disimpulkan bahwa setelah dilakukan analisis internal dan eskternal maka diperoleh lima alternatif strategi PT. Pariwara Advertising yang akan dilakukan. Selanjutnya kelima alternatif strategi inilah yang akan diolah kembali melalui QSPM.

\section{Matriks Strategi Besar (Grand Strategy)}

Matriks strategi besar diperoleh dengan menghitung selisih antara kekuatan dan kelemahan lalu peluang dan ancaman. Berikut adalah hasilnya:
Skor Kekuatan - Skor Kelemahan

$=1,702-0,804$

$=-0,898$

Skor Peluang - Skor Ancaman

$=0,831-1,472$

$=-0,641$

Pada Gambar 4 dapat disimpulkan bahwa Perusahaan di kuadran IV memiliki posisi kompetitif yang kuat namun berada di dalam industri yang pertumbuhannya lambat. Perusahaan-perusahaan ini mempunyai kekuatan untuk mengadakan program diversifikasi ke bidang-bidang pertumbuhan baru yang lebih menjanjikan. Selain itu melalui joint venture, perusahaan dalam kuadran IV akan mampu memperbaiki kondisi perusahaan di masa depan. 


\begin{tabular}{|c|c|c|}
\hline EFAS & $\begin{array}{l}\text { Strengths (S) } \\
\text { (S1) Manajemen puncak } \\
\quad \text { berpengalaman } \\
\text { (S2) Standar produk tinggi } \\
\text { (S3) Tingginya kepercayaan klien } \\
\text { (S4) Budaya Pariwara } \\
\text { (S5) Memiliki } 44 \text { titik iklan di DKI } \\
\quad \text { Jakarta }\end{array}$ & $\begin{array}{l}\text { Weaknesses (W) } \\
\text { (W1) Produk didominasi oleh billboard } \\
\text { (W2) Tingginya turn over karyawan } \\
\text { (W3) Belum mengedukasi klien } \\
\text { (W4) Menurunnya finansial } \\
\text { perusahaan } \\
\text { (W5) Belum ada divisi riset yang } \\
\text { mengukur keandalan produk }\end{array}$ \\
\hline $\begin{array}{l}\text { Opportunities }(\mathrm{O}) \\
\text { (O1) Potensi produk baru (LED, media } \\
\text { sosial, TV) } \\
\text { (O2) Pesatnya perkembangan } \\
\text { teknologi informasi } \\
\text { (O3) Mobilitas Penduduk Tinggi } \\
\text { (O4) Potensi pasar besar seiring } \\
\text { bergeraknya } \\
\text { perekonomian }\end{array}$ & $\begin{array}{l}\text { SO } \\
\text { 1. Menciptakan produk iklan yang } \\
\text { baru mengikuti perkembangan } \\
\text { teknologi informasi seperti } \\
\text { iklan LED media sosial, dan TV } \\
\text { (S2,S3,S5,O1,O2,O3) }\end{array}$ & $\begin{array}{l}\text { WO } \\
\text { 1. Mengelola klien potensial yang } \\
\text { dimiliki dengan edukasi produk } \\
\text { iklan yang kreatif dan inovatif } \\
\text { (W1,W3,O1,O2,O4) } \\
\text { 2. Mengelola modal kerja untuk } \\
\text { membangun tim SDM yang kreatif } \\
\text { dan menciptakan produk baru yang } \\
\text { inovatif (W2,W4,O1,O2) }\end{array}$ \\
\hline $\begin{array}{l}\text { Threats (T) } \\
\text { (T1) Regulasi Pemerintah Daerah DKI } \\
\text { Jakarta } \\
\text { (T2) Persaingan melemah di industri } \\
\text { media luar ruang } \\
\text { (T3) Menurunnya daya beli klien } \\
\text { (T4) Estetika kota } \\
\text { (T5) Persaingan di Industri iklan lain } \\
\text { nya (TV, Media Sosial) }\end{array}$ & \begin{tabular}{l}
\multicolumn{1}{c}{$\mathrm{ST}$} \\
1. Meningkatkan kapasitas SDM \\
untuk menciptakan produk iklan \\
yang berdaya saing tinggi dan \\
sesuai dengan regulasi pemerintah \\
daerah $(\mathrm{S} 1, \mathrm{~S} 4, \mathrm{~T} 1, \mathrm{~T} 2)$
\end{tabular} & $\begin{array}{l}\text { WT } \\
\text { 1. Membangun divisi riset khusus } \\
\text { untuk menciptakan nilai tambah } \\
\text { pada produk dan meningkatkan } \\
\text { daya beli klien (W3,W5,T3,T4,T5) }\end{array}$ \\
\hline
\end{tabular}

Gambar 3. Matriks SWOT PT. Pariwara Advertising

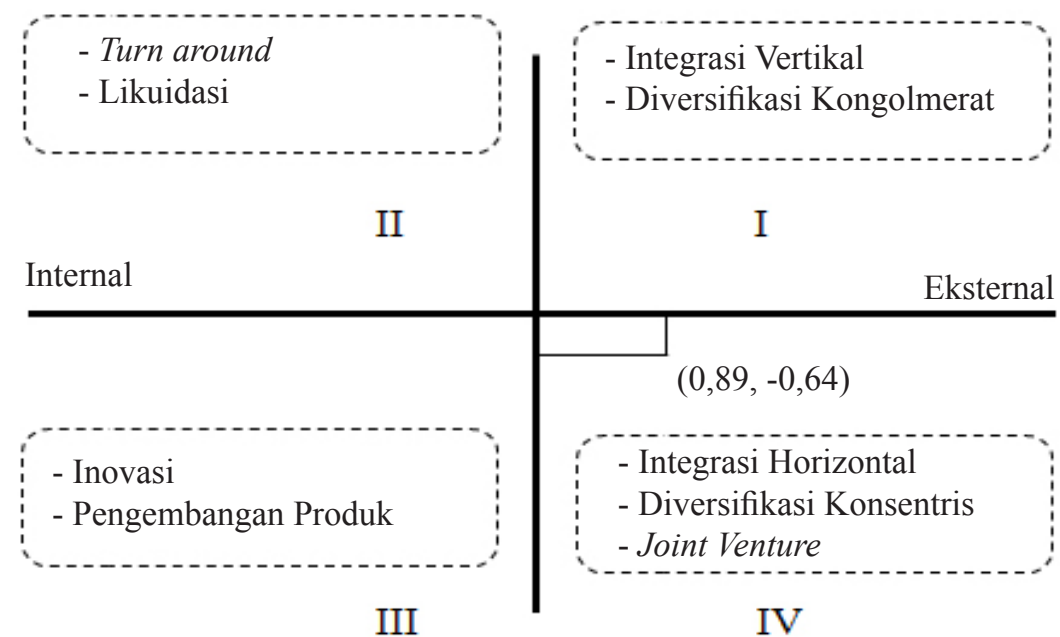

Gambar 4. Matriks Strategi besar

\section{Quantitative Strategic Planning Matrix (QSPM)}

Pada Tabel 6 diperoleh hasil bahwa strategi pertama yangharus dijalankan adalah menciptakan produk iklan yang baru mengikuti perkembangan teknologi informasi seperti iklan LED, media sosial dan TV dengan TAS sebesar 1,663. Lalu mengelola kas perusahaan untuk membangun tim SDM kreatif dan menciptakan produk baru yang inovatif memiliki TAS sebesar 1,538. Ketiga, dengan nilai TAS sebesar 1,474, yaitu membangun divisi riset khusus untuk menciptakan nilai tambah produk dan meningkatkan daya beli klien. 
Tabel 6. Prioritas strategi bisnis PT. Pariwara Advertising (QSPM)

\begin{tabular}{clc}
\hline Peringkat & \multicolumn{1}{c}{ Strategi Alternatif (SA) } & TAS \\
\hline 1 & $\begin{array}{l}\text { Menciptakan produk iklan yang baru mengikuti perkembangan teknologi informasi seperti iklan } \\
\text { LED, media sosial dan TV }\end{array}$ & 1,663 \\
2 & $\begin{array}{l}\text { Mengelola kas perusahaan untuk membangun tim SDM kreatif dan menciptakan produk baru } \\
\text { yang inovatif }\end{array}$ & 1,538 \\
3 & $\begin{array}{l}\text { Membangun divisi riset khusus untuk menciptakan nilai tambah produk dan meningkatkan daya } \\
\text { beli klien }\end{array}$ & 1,474 \\
4 & $\begin{array}{l}\text { Mengelola klien potensial yang dimiliki dengan edukasi produk iklan yang kreatif dan inovatif } \\
5\end{array}$ & $\begin{array}{l}\text { Meningkatkan kapasitas SDM untuk menciptakan produk yang berdaya saing tinggi dan sesuai } \\
\text { denganr regulasi pemerintah daerah DKI Jakarta }\end{array}$ \\
\hline
\end{tabular}

\section{Implikasi Manajerial}

Strategi prioritas pertama yang harus dilakukan oleh PT. Pariwara Advertising adalah strategi diversifikasi konsentris yaitu menciptakan produk iklan yang baru mengikuti perkembangan teknologi informasi seperti iklan LED, media sosial dan TV. Beberapa implikasi strategi yang perlu dilakukan adalah merubah arah perusahan dari media owner menjadi media agensi, melakukan komunikasi dengan semua SDM dan membuat perencanaan dalam menciptakan produk baru perusahaan, mengevaluasi titik iklan yang dimiliki agar terintegrasi dengan produk baru yang mobile dan mengikuti perkembangan e-commerce, joint Venture dengan partner yang sudah berpengalaman di iklan media LED, Media sosial dan TV dan menciptakan produk e-commerce bekerja sama dengan departemen pemerintah yang bertujuan untuk memajukan agribisnis di Indonesia.

\section{KESIMPULAN DAN SARAN}

\section{Kesimpulan}

Kondisi internal PT. Pariwara Advertising adalah memiliki kekuatan dalam hal kepercayaan klien juga budaya perusahaan yang kuat menghasilkan kapasitas perusahaan yang sebenarnya bisa terus bersaing di industri selain media luar ruang. Kondisi eksternal PT. Pariwara Advertising berupa ancaman yang paling kuat untuk perusahaan adalah regulasi pemerintah daerah DKI Jakarta. Di awal tahun 2015, dengan adanya Pergub No. 1 Tahun 2015 tentang Larangan Penyelenggaraan Reklame Rokok dan Produk Tembakau pada Media Luar Ruang menyebabkan lemahnya pertumbuhan industri media luar ruang.
Prioritas strategi yang harus dilakukan oleh PT. Pariwara Advertising adalah diversifikasi konsentris, yaitu menciptakan produk iklan baru mengikuti perkembangan teknologi informasi seperti iklan LED, media sosial dan TV. Langkah konkrit yang dilakukan adalah dengan merubah fokus perusahaan dari media owner menjadi media agency sehingga pangsa pasar PT. Pariwara Advertising lebih luas.

\section{Saran}

Kapasitas PT. Pariwara Advertising seperti strategi perusahaan, produk-produk media luar ruang dan kemampuan SDM seharusnya dapat terus ditingkatkan seiring dengan perubahan dan perkembangan lingkungan industri media luar ruang. Kemampuan manajemen dalam menangkap pergerakan industri sangat dibutuhkan dalam beradaptasi dan memilih prioritas strategi perusahaan. Penelitian lebih lanjut juga diperlukan untuk mengkaji secara mendalam bagaimana pelaku bisnis media luar ruang dapat terus beriringan dengan peraturan Pemerintah Daerah setempat.

\section{DAFTAR PUSTAKA}

Anwar CM, Utami CM. 2012. Analisis SWOT pada strategi bisnis dalam kompetisi pasar (studi kasus: toko pojok madura). Jurnal Sistem Informasi 5(1): 1-9.

Bachdar S. 2015. Iklan rokok dilarang billboard kosong melompong. http://marketeers.com. [01 Maret 2016]

David FR. 2006. Manajemen Strategis. Ed. ke-10. Jakarta: Salemba Empat.

Defriza D. 2006. Studi pengaruh iklan luar ruang sebagai faktor pembentuk "sense of place" ruang kota. Jurnal Sistem Teknik Industri 7(1): 73-81. 
Ekomadyo. 2008. Phenomena of aesthetic creative outdoor advertising in urban. department of architecture school of architecture, planning, and policy development institute of technology. Bandung. International Conference Arte-Polis 2: 11-19.

Francese P. 2003. More home less. American demographics 25(8): 40-41.

Ginting. 2006. Perumusan Strategi Perusahaan PT X menggunakan matriks evaluasi faktor. Jurnal Sistem Teknik Industri 7(1): 1-5.

Guyana J, Mustamu R. 2013. Perumusan strategi bersaing perusahaan yang bergerak dalam industri pelayaran. program manajemen bisnis. AGORA 1(3): 1-12.

Harysakti A. 2013. Perencanaan pembangunan media luar ruang tanpa sampah visual guna menunjang kesejahteraan warga Kota Malang. Malang: Pascasarjana Arsitektur Lingkungan Binaan. Universitas Brawijaya.

Isnandar RF. 2016. Strategi peningkatan aset PT BPR Syariah Harta Insan Karimah (HIK) Ciledug. Jurnal Aplikasi Bisnis dan Manajemen. 2(1): 12-22.

Idris, Muhammad. 2015. Ahok larang iklan rokok, binsis baliho dan billboard lesu. http.finance. detik.com. [02 Maret 2016)

Jannah EM, Rahman A, Yuniarti R. 2013. Penentuan strategi bersaing perusahaan berdasarkan pengukuran kinerja dengan Metode Malcoln Balridge National Quality Award (MBNQA). Jurnal Rekayasa dan Manajemen Sistem Industri 1(1): 11-21.

Juniarko O. 2013. Penataan reklame pada koridor jalan utama Kota Mataram. Jurnal Tata Kota dan Daerah 1(2): 83-86.

Kumar, Anil. 2012. The Effect of Billboards Advertisement on Consumer (A study of Kurukshetra \& Kaithal cities of Haryana State). CBS Group of Institutions, Jhajjar (Haryana).1(1): 44-53.

Lubis, Mila. 2016. Belanja iklan tumbuh positif di tahun 2015. http:nielsen.com. [30 Maret 2016]

Lukito V, Lianto B, Surjani R. 2013. Perancangan strategi bisnis di PT. Coronet Crown. Jurnal Ilmiah Mahasiswa Universitas Surabaya 2(1): $1-19$.

Rahadian. 2015.Ahok siapkan pergub larangan reklame. http//cnnindonesia.com. [20 Maret 2016]

Rahmana A, Iriani Y, Oktarina O. 2013. Strategi pengembangan usaha kecil menengah sektor industri pengolahan. Jurnal Teknik Industri 20(1): 14-21.

Rangkuti F. 2004. Analisis SWOT Teknik Membedah Kasus Bisnis. Jakarta: PT. Gramedia.

Retnowati D N. 2011. Analisis CSF, SWOT dan TOWS Studi Kasus: PT Intan Pariwara Klaten. Jurnal Buana Informatika 2(1): 31-37.

Setiawan A, Rukmi SH, Bakar A. 2015. Strategi pengembangan UKM pengolahan kulit sapi di kabupaten Garut menggunakan matrik perumusan strategi. Jurnal Online Institut Teknologi Nasional 3(3): 218-229.

Sholehana, Amalia. 2012. Formulasi strategi peningkatan produksi domba CV. Mitra Tani Farm Ciampea, Bogor. Jurnal Manajemen \& Agribisnis 9(2): 77-85.

Sholihin, Ustadus. 2014.Analisis strategi pemasaran dalam menghadapi persaingan usaha pada perusahaan kain dan sarung tenun ikat cap sinar barokah kediri. Jurnal Cendekia 12(3): 1-6.

Smarter. 2015. City Friendly Advertising : Preliminary Research. Jakarta: PT. Pariwara Advertising

Soesatyo N, Rumambi JL. 2013. Analisis credibility celebrity endorser model: sikap audience terhadap iklan dan merek serta pengaruhnya pada minat beli "top coffe". Jurnal Manajemen Pemasaran 1(2): 1-12.

Suyitman, Sutjahjo SH, Herison C, Muladno. 2009. Status keberlanjutan wilayah berbasis peternakan di Kabupaten Situbondo untuk pengembangan kawasan agropolitan. Jurnal Agroekonomi 27(2): 165-191.

Taylor R, Charles, Jhon P. 2006. The Value of Exposure Provided by Outdoor Advertising: A Critique of Outdoor Advertising Visibility Adjustments. Villanova University.

Thamrin. 2010. Pengolahan data permohonan pemasangan reklame pada kantor balai Kota Padang. Jurnal Teknologi Informasi dan Pendidikan 1: 133-143.

Wicaksono, Susilo, Lestari Puji. 2008. Iklan luar ruang : antara kepentingan ekonomi dengan kepentingan publik. UPN "Veteran" Yogyakarta. Jurnal Ilmu Komunikasi 6: 131-144.

Zulkarnaen H, Sutopo. 2013. Analisis strategi pemasaran pada usaha kecil menengah (UKM) makanan ringan (studi penelitian UKM snack barokah di Solo). Journal of Management 2(3): $1-13$. 